\title{
A Qualitative Content Analysis of Spirituality and Religiosity amongst Greek COPD Patients
}

\author{
Efthymios Tzounis ${ }^{1, *}$, Theodora Kerenidi ${ }^{2}$, Zoe Daniil $^{3}$, Chryssi Hatzoglou ${ }^{4}$, \\ Evangelia Kotrotsiou ${ }^{5}$ and Konstantinos Gourgoulianis ${ }^{6}$ \\ 1 Primary National Health Network, Health Unit Volos, Volos 38445, Greece \\ 2 Respiratory Department, Medical School, University of Thessaly, Volos 38333, Greece; thkeren@med.uth.gr \\ 3 Respiratory Department, Medical School, University Hospital of Larissa 41222, Greece; zdaniil@med.uth.gr \\ 4 Department of Physiology, Medical School, University Hospital of Larissa 41222, Greece; chatz@med.uth.gr \\ 5 Department of Nursing, Technological Educational Institute of Larissa, Larissa 41222, Greece; \\ kotrotsi@teilar.gr \\ 6 Respiratory Department, Medical School, University of Thessaly, Larissa 41222 Greece; kgourg@med.uth.gr \\ * Correspondence: etzounis@yahoo.gr; Tel.: +30-24210-67231
}

Academic Editor: Arndt Büssing

Received: 1 November 2015; Accepted: 19 February 2016; Published: 1 March 2016

\begin{abstract}
Chronic Obstructive Pulmonary Disease (COPD) is a chronic and common disease throughout the world. Spiritual/religious beliefs are often central to patients with serious illnesses and could serve as a resource for coping with such illnesses. A qualitative methodology was chosen in order to gain a thorough understanding of 75 (male $n=69,92 \%$, female $n=6,8 \%$ ) Greek COPD patients' perceptions of spirituality and religiosity and explore the importance of practicing their beliefs while 25 patients refused to participate in the study. The fewer female participant patients in the study are related to the lower percentage of women suffering from COPD in Greece, which can be further linked to the low smoking habit of women. A total of four patients $(5.3 \%)$ stated that they had no religious or spiritual understanding of their life; 41 (54.7\%) reported a religious belief; eight $(10.7 \%)$ told of a spiritual belief; and $22(29.3 \%)$ of the participants reported both a religious and a spiritual belief. Faith in the will of God seems to be a particularly strong feature of patients' beliefs. Praying and church attendance were more likely to confirm the importance of practicing their beliefs in their daily lives but COPD seems to prevent patients from regular churchgoing. Religion and spirituality were found to be helpful while patients did not seem to have unrealistic expectations from God when dealing with illness. When asked, participants defined spirituality as "happiness", "love", "our God", "the spirit", and as an act of altruism. Adopting a more holistic perspective for COPD patients in the clinical setting, spirituality and religiosity can offer suggestions for interventions related to their health issues.
\end{abstract}

Keywords: Greek COPD patients; spirituality; religiosity; quantitative research

\section{Introduction}

Chronic Obstructive Pulmonary Disease (COPD) is a chronic disease which is among the most common ones around the world [1]. Shortness of breath and cough are the most troublesome symptoms that can reduce quality of life [2] and prevent patients from participating in social relations and experiencing well-being [3]. COPD is characterized by airflow limitation and inflammation while patients with COPD face a significantly increased risk of premature death [4]. Compared to other chronic diseases, patients living with COPD tend to report worse psychological functioning and psychiatric distress $[5,6]$. COPD patients are identified with severe dyspnea, and psychological 
burden of clinically relevant anxiety or depression [7]. These symptoms also affect the patients' quality of life as most of the patients are in need of continuous support and care [8]. Health is multidimensional and this realization requires a degree of balance among diverse elements such as physical, emotional, intellectual, social, and spiritual health [9]. Holistic healing requires attention when related to psychological, social and spiritual disturbances [10]. Providing holistic care for patients through more integrated approaches consists a necessity [11] as it can increase the care providers' depth of understanding when related to patients and their needs [12].

Spiritual/religious beliefs are often central to patients with serious illnesses and serve as a resource for coping with illness $[13,14]$. Spirituality is a multidimensional concept and "it should not be assumed that is either synonymous or coterminous, with religion." [15]. According to the definition of MacKinlay (2001), spirituality is "not only constituted by religious practices, but it is understood more broadly, as a relationship with God, however God or ultimate meaning is perceived by the person, and in relationship with other people" [16]. Reed (1992) states that spirituality is a form of self-transcendence. She also notes that "spirituality is an individualized awareness of one's inner self and a sense of conjunction with a powerful dimension or purpose" [17]. Spirituality has also been conceptualized as including an individual's transcendent relationship with the higher being or with the universe and hence has been linked to hope, coping, and religiosity [18]. Some researchers claim that spirituality incorporates a sense of meaning and purpose that may or may not be aligned with formal religious beliefs or practices $[19,20]$. Despite the conflict on terminology that is related to spirituality, the definitions of religion are generally agreed upon [19]. Religion refers to an organized system of beliefs, practices, and ways of worship [21]. Religiosity refers to participation in activities and rituals of traditional religion and is a "nurturer and channel of expression" for spirituality [22].

The role of spirituality / religiosity in the promotion of health has been discussed in various medical publications. This interest in examining the interaction of spirituality with health-related outcomes has been continuous [23] but less attention has been given to the spiritual beliefs of COPD patients.

COPD is a progressive illness. Throughout the various stages of COPD, the patients' needs tend to become more complex as their daily habits are affected in many different ways. Spiritual/religious care could improve COPD patients' quality of life as for instance, by relieving their spiritual pain and suffering. The authors believed it was important to analyze the patients's spirituality/religiosity so as to find out if they have realistic expectations when reporting their religious and spiritual beliefs while dealing with COPD. The research team also assumed that it could be beneficial for health care providers to recognize COPD patients' spiritual / religious needs and include them in the clinical care setting.

Because there has only been limited investigation into the relationship between COPD patients' perceptions of spirituality and their health status, this paper proposes to study from an empirical and qualitative point of view the following topics:

(a) COPD patients understanding of spirituality.

(b) What the spiritual/religious beliefs and practices of COPD patients are and how they affect their daily life.

(c) What the form of communication with the spiritual power takes.

(d) What the patient's understanding is of what happens after death.

(e) The relationship between the role of spirituality and health status as perceived by COPD patients.

\section{Methods and Materials}

\subsection{Setting and Participants}

The study was conducted at the University Public Hospital of Larissa, Greece. The sample consisted of 75 COPD patients living in northern- central Greece. We enrolled 75 consecutive COPD patients varying from mild to very severe airflow limitation (GOLD stage I to IV). All subjects were evaluated in the COPD outpatient clinic of the Pulmonary Department. 
Inclusion criteria included: an age limit greater than 40 years, a diagnosis of COPD established according to the GOLD (Global initiative for chronic Obstructive Lung Disease) criteria, the ability of the patients to provide data about their disease history, comprehension of the aim of the study and patient consent to participate in the study.

Exclusion criteria included patients who were non-Greek speaking, mentally-impaired, unaware of their diagnosis, or otherwise unable to consent to or participate in the interview process.

The participants' socio-demographic characteristics are shown in Table 1 . Their mean age was 69.67 years (range, $43-86$ years); $92 \%(n=69)$ were men and $8 \%(n=6)$ women. Fifty-seven patients $(76 \%)$ were living with a companion while $10(13.3 \%)$ were living alone. Seven patients $(9.3 \%)$ were living at a nursing home or were accommodated by relatives. Forty-one (55.4\%) participants used to live in an urban area while $13(17.6 \%)$ in a suburban and $20(27 \%)$ in a rural area. Four patients were uneducated (5.3\%), 58 (77.3\%) graduated from primary school, $9(12 \%)$ graduated from junior high school, $2(2.7 \%)$ graduated from high school and $2(2.7 \%)$ were university graduates.

Table 1. Socio-demographic characteristics of COPD patients.

\begin{tabular}{|c|c|c|}
\hline \multicolumn{3}{|c|}{ Age, Mean (Range) 69.67 (43-86) } \\
\hline Groups & $n$ & $(\%)$ \\
\hline $40-49$ & 1 & $(1.33)$ \\
\hline $50-59$ & 8 & $(10.66)$ \\
\hline $60-69$ & 24 & $(32)$ \\
\hline $70-79$ & 28 & $(37.33)$ \\
\hline $80-85$ & 14 & $(18.66)$ \\
\hline Gender & $n$ & $(\%)$ \\
\hline Male & 69 & (92) \\
\hline Female & 6 & (8) \\
\hline Marital Status & $\mathrm{n}$ & $(\%)$ \\
\hline Married & 57 & (77) \\
\hline Divorced & 2 & $(2.7)$ \\
\hline Widowed & 6 & $(8.1)$ \\
\hline Single & 9 & $(12.2)$ \\
\hline Labour Market Status & $n$ & $(\%)$ \\
\hline Employed & 12 & $(16)$ \\
\hline Unemployed & 1 & $(1.3)$ \\
\hline Pensioner & 60 & $(80)$ \\
\hline Home manager & 2 & (2.7) \\
\hline
\end{tabular}

Disease data are shown in Table 2.

Table 2. Disease data.

\begin{tabular}{clc}
\hline Spirometric Classification & $\boldsymbol{n}$ & $\mathbf{( \% )}$ \\
\hline Mild COPD & 3 & $(4)$ \\
Moderate COPD & 36 & $(48)$ \\
Severe COPD & 29 & $(38.7)$ \\
Very severe COPD & 7 & $(9.3)$ \\
\hline Smoking Habits & $\boldsymbol{n}$ & $\mathbf{( \% )}$ \\
\hline Smoker & 34 & $(45.9)$ \\
\hline
\end{tabular}


Table 2. Cont.

\begin{tabular}{ccc}
\hline Spirometric Classification & $\boldsymbol{n}$ & $\mathbf{( \% )}$ \\
\hline Ex-Smoker & 40 & $(54.1)$ \\
\hline Respiratory Failure & $\boldsymbol{n}$ & $\mathbf{( \% )}$ \\
\hline Yes & 12 & $(16.2)$ \\
No & 62 & $(83.8)$ \\
\hline Dyspnea & $\boldsymbol{n}$ & $\mathbf{( \% )}$ \\
\hline Yes & 73 & $(97.3)$ \\
No & 2 & $(2.7)$ \\
\hline Self-report Heath Status & $\boldsymbol{n}$ & $\mathbf{( \% )}$ \\
\hline Very good & 4 & $(3.3)$ \\
Good & 16 & $(13.2)$ \\
Moderate & 35 & $(28.9)$ \\
Bad & 16 & $(13.2)$ \\
Very bad & 4 & $(3.3)$ \\
\hline
\end{tabular}

A total of 4 out of 75 patients (5.3\%) stated that they had no religious or spiritual understanding of their life; 41 (54.7\%) reported a religious belief; $8(10.7 \%)$ told of a spiritual belief and 22 of participants $(29.3 \%)$ reported both a religious and a spiritual belief.

\subsection{Procedure and Analysis}

One hundred and ten patients were invited to join the study on the dates scheduled for their visits to the COPD outpatient clinic of the Pulmonary Department. Seventy-five COPD patients accepted the invitation so as to participate in the study providing written consent. Sixty-eight participants were interviewed in the outpatient clinic, after their visit to the doctor.

Seven patients, who were suffering from severe or very severe COPD did not attend their scheduled visits to the COPD outpatient clinic because they were hospitalized during that period of time. These seven COPD patients were interviewed at their nursing rooms.

Although a written explanation was given in relation to the nature and objectives of the study, 25 patients who were invited to participate did not accept the invitation. These patients refused to participate stating that neither religiosity nor spirituality should be discussed in a clinical setting. Although they wanted to participate in the study, ten patients were excluded because they refused to provide written consent which was a prerequisite of the study.

A qualitative methodology [24] was chosen in order to gain a detailed understanding of the patients' spiritual/religious beliefs, experiences, and definitions. Qualitative research can provide helpful details concerning spirituality in clinical practice [25]. Qualitative methodology has one significant advantage in which the researcher can explore a smaller number of cases but in greater depth [26].

This study provides an in-depth description of spirituality and religiosity after a face-to-face interview with the informants. Data were collected using an interview guide (Appendix A) so as to encourage conversation with the patients. All interviews were recorded, typed and later labeled with a code (Patient-Participant: 1 up to 75) to ensure the anonymity of every patient after the interview. Typed data were also checked for accuracy against the mp3 recordings. Words and phrases that were mentioned more frequently were often those reflecting the most important concepts in this communication with the patients. Participants most important statements were underscored, organized and later transferred to a "data base". The multidisciplinary team compared the cases and identified both their similarities and differences while their interpretation was influenced by the researchers' diverse professional backgrounds. The researchers detected six main themes: (1) the form of patients' Spiritual/Religious beliefs; (2) the practice of belief (subthemes: (a) praying and 
(b) ceremony and church attendance); (3) connection and communication with God, Higher Power or Spirit; (4) a form of existence after death; (5) expressions and definitions of spirituality; and (6) spirituality/religiosity and illness management. Coding guide and patient specific data are shown in Table 3.

Table 3. Patient specific data.

\begin{tabular}{|c|c|c|c|c|c|c|}
\hline Patient & Sex & Age & COPD & Education & $\begin{array}{l}\text { Spiritual and/or Religious } \\
\text { Understanding of Life }\end{array}$ & $\begin{array}{c}\text { Self-Report } \\
\text { Health Status }\end{array}$ \\
\hline 1 & Male & 83 & Severe & Primary & Religious & Bad \\
\hline 2 & Male & 81 & Severe & Primary & Religious & Very bad \\
\hline 3 & Male & 69 & Very severe & Primary & Religious & $\mathrm{Bad}$ \\
\hline 4 & Male & 71 & Severe & Primary & Religious & Good \\
\hline 5 & Male & 68 & Severe & Primary & Religious & Moderate \\
\hline 6 & Male & 73 & Severe & Uneducated & Spiritual and religious & Moderate \\
\hline 7 & Male & 84 & Severe & Uneducated & Religious & Bad \\
\hline 8 & Male & 76 & Moderate & Primary & Religious & Moderate \\
\hline 9 & Male & 69 & Moderate & Primary & Spiritual and religious & Good \\
\hline 10 & Male & 81 & Severe & Primary & Religious & Moderate \\
\hline 11 & Male & 61 & Moderate & Primary & Religious & Moderate \\
\hline 12 & Male & 64 & Very severe & Primary & Spiritual and religious & Moderate \\
\hline 13 & Male & 70 & Very severe & Primary & Spiritual & $\mathrm{Bad}$ \\
\hline 14 & Male & 75 & Very severe & Primary & Spiritual and religious & Bad \\
\hline 15 & Male & 78 & Moderate & Primary & Spiritual and religious & Good \\
\hline 16 & Male & 86 & Severe & Primary & Religious & Moderate \\
\hline 17 & Male & 80 & Moderate & Primary & Spiritual and religious & Bad \\
\hline 18 & Male & 68 & Severe & Junior High School & Spiritual and religious & Very good \\
\hline 19 & Male & 64 & Mild & Primary & Religious & Moderate \\
\hline 20 & Male & 76 & Severe & Junior High School & Religious & Moderate \\
\hline 21 & Male & 70 & Moderate & Primary & Religious & Good \\
\hline 22 & Male & 70 & Moderate & Primary & Spiritual and religious & Moderate \\
\hline 23 & Male & 63 & Severe & Primary & Spiritual and religious & Moderate \\
\hline 24 & Female & 84 & Severe & Primary & Religious & Moderate \\
\hline 25 & Male & 43 & Moderate & Junior High School & Religious & Moderate \\
\hline 26 & Male & 62 & Very severe & Primary & None & Moderate \\
\hline 27 & Male & 84 & Moderate & Primary & Spiritual & Good \\
\hline 28 & Male & 72 & Moderate & Primary & Religious & $\mathrm{Bad}$ \\
\hline 29 & Male & 84 & Severe & Primary & Religious & Moderate \\
\hline 30 & Male & 54 & Moderate & Junior High School & Religious & Good \\
\hline 31 & Male & 60 & Moderate & Primary & Religious & Moderate \\
\hline 32 & Male & 57 & Severe & High School & Spiritual & Moderate \\
\hline 33 & Male & 72 & Severe & Primary & none & Good \\
\hline 34 & Male & 84 & Mild & Primary & Religious & Moderate \\
\hline 35 & Male & 50 & Moderate & Primary & Spiritual and religious & Good \\
\hline 36 & Male & 85 & Moderate & Primary & Religious & Moderate \\
\hline 37 & Male & 58 & Severe & Junior High School & Spiritual and religious & $\mathrm{Bad}$ \\
\hline
\end{tabular}


Table 3. Cont.

\begin{tabular}{|c|c|c|c|c|c|c|}
\hline Patient & Sex & Age & COPD & Education & $\begin{array}{l}\text { Spiritual and/or Religious } \\
\text { Understanding of Life }\end{array}$ & $\begin{array}{c}\text { Self-Report } \\
\text { Health Status }\end{array}$ \\
\hline 38 & Male & 70 & Moderate & Primary & Spiritual and religious & Moderate \\
\hline 39 & Male & 77 & Severe & Primary & Spiritual & Very bad \\
\hline 40 & Male & 77 & Mild & Primary & Religious & Very good \\
\hline 41 & Male & 83 & Moderate & Primary & Religious & Moderate \\
\hline 42 & Male & 58 & Severe & Junior High School & none & $\mathrm{Bad}$ \\
\hline 43 & Male & 53 & Moderate & Primary & Religious & Moderate \\
\hline 44 & Male & 67 & Moderate & Primary & Religious & Moderate \\
\hline 45 & Male & 67 & Severe & University & Spiritual and religious & Moderate \\
\hline 46 & Female & 68 & Severe & Primary & Religious & Bad \\
\hline 47 & Male & 75 & Moderate & Primary & Religious & $\mathrm{Bad}$ \\
\hline 48 & Male & 63 & Moderate & Primary & Spiritual and religious & Good \\
\hline 49 & Male & 73 & Moderate & Primary & Religious & Moderate \\
\hline 50 & Male & 72 & Severe & Primary & Religious & Very bad \\
\hline 51 & Male & 58 & Moderate & Primary & Spiritual and religious & Good \\
\hline 52 & Male & 53 & Moderate & Junior High School & Spiritual and religious & Good \\
\hline 53 & Male & 75 & Severe & Primary & Religious & Bad \\
\hline 54 & Male & 82 & Severe & Primary & Religious & Bad \\
\hline 55 & Female & 78 & Moderate & Uneducated & Religious & Moderate \\
\hline 56 & Male & 60 & Severe & Primary & Spiritual & Bad \\
\hline 57 & Male & 80 & Very severe & Primary & Spiritual & $\mathrm{Bad}$ \\
\hline 58 & Male & 72 & Very severe & Uneducated & Spiritual & Moderate \\
\hline 59 & Male & 70 & Moderate & High School & Religious & Good \\
\hline 60 & Male & 71 & Severe & Primary & Religious & Bad \\
\hline 61 & Male & 61 & Moderate & Primary & Spiritual and religious & Moderate \\
\hline 62 & Male & 70 & Moderate & Primary & Religious & Moderate \\
\hline 63 & Male & 64 & Moderate & Primary & Spiritual and religious & Good \\
\hline 64 & Male & 78 & Moderate & Primary & Religious & Moderate \\
\hline 65 & Female & 61 & Moderate & Primary & Religious & Moderate \\
\hline 66 & Male & 70 & Severe & University & Spiritual & Moderate \\
\hline 67 & male & 68 & Severe & Junior High School & Spiritual and religious & Good \\
\hline 68 & male & 64 & Severe & primary & Spiritual and religious & Moderate \\
\hline 69 & male & 73 & Moderate & primary & Religious & Moderate \\
\hline 70 & male & 67 & Moderate & primary & Religious & Very good \\
\hline 71 & male & 71 & Moderate & primary & Religious & Very good \\
\hline 72 & male & 65 & Moderate & primary & Spiritual and religious & Good \\
\hline 73 & female & 78 & Moderate & Junior High School & Religious & Moderate \\
\hline 74 & male & 68 & Severe & primary & none & Very bad \\
\hline 75 & female & 61 & Moderate & primary & Spiritual and religious & Good \\
\hline
\end{tabular}

Researchers completed a questionnaire that included the patients' demographics (age, sex and labor market status), period of time since COPD diagnosis, comorbidities, and educational status. Most questions from the interview guide (Appendix A) are drawn from the Greek version of the "Royal 
Free Interview for Religious and Spiritual Beliefs". A question for the patients self-rated health and an open question asking participants if spirituality/religiosity helps them cope with their problems were also included. Participants were further asked to define spirituality or try to describe it in case they do not fully comprehend the term. Self-rated health (SRH) is one of the most frequently assessed health perceptions in epidemiological research. Although the answer to the self-rated health question is subjective, it is nevertheless a powerful predictor of future morbidity and mortality [27]. In 1995, King et al. developed and in 2001 modified, "The Royal Free Interview for Religious and Spiritual Beliefs" in order to evaluate religious and spiritual beliefs in a variety of populations $[28,29]$. The Greek version of the "Royal Free Interview for Religious and Spiritual Beliefs" proved to have satisfactory psychometric properties for the Greek population [30,31].

In this research, credibility was established while the authors were in constant interpersonal interaction with the patients. The issues of spirituality and religiosity were discussed freely without taboo biases and prejudices. The professors supervised the research team in every step of the conducted process.

\subsection{Ethical Consideration}

First and foremost, participation in this study was voluntary. Informed consent was attained on the specific day of the interview. The patients participating in the study also consented to their being recorded during their interviews. Participants were further informed that they could cease the interview at any stage of the study.

\section{Participant Interviews}

\subsection{The Form of Spiritual/Religious Beliefs}

We asked participants to provide us with a brief interpretation of their religious or spiritual beliefs. Note that the patient number in parenthesis after each quotation corresponds to the specific patient number identified in Table 3.

For patients, both those who self-identify as spiritual/religious and those who do not, spirituality is an important dimension of their lives. The patient seeks control on his disease through a partnership with God and asks for God's forgiveness.

“God is one. You will eventually believe. We wouldn't be able to live or walk if it wasn't for God." (Patient 39).

Another patient noted that he tries to live his life according to his spiritual and religious beliefs. Trusting in God and having faith are important in one's daily life. This patient reported becoming more spiritual and religious after experiencing a life threating disease.

"I have both a religious and a spiritual understanding of life. I deeply believe, I don't curse, I go to the church as frequently as possible, I light a candle and attend mass whenever I can. Having experienced a stroke led me closer to God." (Patient 48).

He also expressed the need to believe in Sainthood where Saints intercede for him when he is in difficulty. It seems that God is "accessible" through the help of the Saints. Maybe some of our participants believe that God and the Saints "live" and "co-operate" together.

"I am really close to religion, both religiously and spiritually. I have had great value for this since my early youth ... Whenever I asked the help of the Saints, the next day, if not sooner, they do what I had asked them. I always have St. Joseph's protection." (Patient 48).

Spirituality implies a relationship with a higher being or God. One's relationship with God is linked to personal perceptions and experiences. 
"I have a spiritual understanding of life. I believe there is a higher power. Now, what's that? Only God knows ... The higher power can do anything, we can do nothing. Humanity is spiteful because we spite one another." (Patient 27).

God reveals Himself through nature and nature reveals God's presence. The patient cannot see God, but he believes he sees the evidence of His existence through nature.

"I am a religious and spiritual person. Whatever someone believes in can only be good ... Nature and God, that's what we were told." (Patient 38).

One of the patients noted that he does not have to ignore his spiritual and religious beliefs because of what other people think of him. The church was a place where he could grow into being Christian. The patient tried to retain his bond with the local church when he grew older.

"Us Greeks always operate under traditions ... I revere St. Nicholas, which means if I come across a temple, I make the sign of the cross. I'm not embarrassed; some people are embarrassed to do it. Merely lighting a candle in church to be seen by others is a little phony, I think." (Patient 61).

A patient explained the reason why he has neither a religious nor a spiritual understanding of life. Negative views and perceptions regarding religiosity were expressed by the specific COPD patient.

"I don't believe in such things. Why? Should I lie about it? I say no for churches and stuff ... these are old things. Go and light a candle in the church? Search for what? There's no mood for that now, and I am ill." (Patient 74).

\subsection{Practice of Belief}

\subsubsection{Praying}

Praying may benefit people suffering from COPD in a number of ways, and one of the most important functions has to do with reinforcing religious beliefs.

"Praying? Here in the nursing room, it is done fast when I was home it was necessary ...

I thank God a million times." (Patient 34).

Participants believe that it is important to pray to the saints as they believe that they are working with them to solve their problems.

"From a very young age, I have always been faithful to God and Jesus. Whatever happened to me while ... I would go to the church, I would pray to Jesus, to the Saints. When I pray, I envision the holy figure I am praying to." (Patient 9).

Isolation and time spent in each prayer activity were also associated with resolving their problems. People with strong faith assume that God and Saints are omnipresent and omnipotent. Maybe that is why they believe prayer "urges" God to address their wishes.

"When alone, I pray a lot during the day, I pray a lot for life's troubles. I rely on my prayers and I am relieved in this way. On St Lucas day, that's the prayer I have all the time." (Patient 61).

"Sometimes I speak to God when I'm alone." (Patient 13).

Icons represent a part of the spirituality of the Greek Orthodox Christian culture and can serve as a means of constant communication with God or the Saints. For patients, icons seem to be a part of the Church's preaching and praying. 
"I pray and talk to the icons of saints that I have at home. Do I need an icon at the hospital? Yes. I bought an icon of St Raphael." (Patient 47).

The sign of the Cross is the original and most commonly used symbol of prayer of the Christian faith. It is taught that one crosses oneself when they begin their prayers. For the following patient, the formation of the Cross is a request for God's blessing.

"I am sure when I make the sign of the cross and whatever God says will happen, will happen ... then I feel stable." (Patient 49).

Formatting the sign of the cross is a prayer in itself. This life-giving symbol has been adopted as a daily procedure for some of the participants.

"Spirituality and religion are everything to me. I am the kind of man who would get up every morning to go to work and I would make the sign of the cross. I have rarely attended church and I still rarely visit it, but I do believe." (Patient 23).

Only a few patients referred to meditation. Among them one patient stated that:

"I try thinking less, it's my philosophy ... Meditation is a way-out. At that moment of reflection, I find a solution; I can say I am satisfied. If I don't come up with a solution I then say to myself "Wrong thought again ... " (Patient 61).

\subsubsection{Ceremony}

The participants tend to shape a relationship with God or a spiritual power within and outside of the church. The following examples support the fact that spirituality is present both to the believers and the non-believers.

Being present at the local Christian church frequently was a priority for the next participant, despite his age and his serious health problems that almost led him to death.

"I go to church every Sunday, but if I'm sick, I don't. I am alive therefore I am happy. I had reached a point where I said to myself: I should 'rest' now." (Patient 27).

Despite the decline of formal beliefs and practices, the following patient still regards the idea of spirituality as essential to his life. While suffering from very severe COPD he seems to find spiritual comfort when visiting his dead brother.

"I respect and I will respect the church. I might well go to the cemetery just for release, to light a candle for my brother and my niece. I will then light up a cigarette and would feel like I've been flying." (Patient 26).

The pivotal role of church attendance proved to be helpful for our participants. Church is thought to be their "sanctuary" where they can communicate with God more easily.

"I attend religious ceremonies. It helps me because of my bad health status. I pray but I do not confess, I don't feel the need to do so." (Patient 12).

Regular churchgoers seem to go there for a reason. Patients seek control to the disease through their "partnership" with God and find support within the religious community.

"I believe that God can help me with my health problems and that's why I attend church services very often." (Patient 16).

Patients have often stated that religious ceremonies play a central role in their faith. Religious service attendance was found to provide comfort and positive indications of emotional health. 
"I have a religious understanding of life. When I go to church, I feel relieved." (Patient 36).

Going to church was the last remaining activity for the next patient outside of the nursing home. People who have limited access to religious services try to find a way to express their spiritual needs by going to the church and forgetting the problems that trouble them.

“-Does religion provide any source of support for you?

-Yes, it makes you forget some problems. If you go to church and devote yourself to it, then somehow you move away from mundane things." (Patient 8).

For the last five years, Greeks have faced many economic problems. Many people are fed from soup kitchens or receive food supplies. The majority of the local soup kitchens are run by the Greek Orthodox Church. People have to travel long distances which are away from their neighbors' prying eyes to receive this help.

"In my village, they would say: He is poor, that's why he goes to church. But here in the city, there is no gossiping. People don't know who you are." (Patient 9).

\subsection{Connection and communication with God, a Higher Power or Spirit}

Even when dealing with severe COPD, a particular patient did not seem to be afraid of the disease or facing it fatalistically. For him, the communication with a spiritual power-via church attendance-was an act of help and support. In order for this communication to be successful, the patient's entire being must be congruent with this goal.

"I am neither panicked nor scared; if we are meant to live then, be it ... I believe in this thing called a higher power. I go to church; I'm not going there to see whether somebody has a nice suit or shoes, I go because I believe in the higher power. Sometimes when I need it, I believe the higher power helps me." (Patient 68).

If anyone wants to establish communication with a spiritual power, the first step is to believe in its existence. When a person denies the existence of a higher power then, no communication can be established. A patient expressed his point of view that "in the materialistic world we live in" all things come from "human power".

"I don't think a spiritual power affects anything in my life ... People do everything; whatever happens is because of us." (Patient 23).

Contact with the spiritual world is a part of everyday life for many people, especially through prayer. For these people, only faith is needed in order to communicate with the spiritual world.

"I communicate with God through praying." (Patient 16).

\subsection{A Form of Existence after Death}

We asked the participants whether they believe that people exist in some form after their death. Universal beliefs that the human soul survives death were expressed by COPD patients. Some participants also believed in life after death. A patient perceived death not as an end but as a transition from this life to the next.

"I believe that the soul is not lost; it is reborn in a new life and has another mission. This cannot be examined and I don't want to examine it." (Patient 48).

As it was reported, dyspnea was the worst symptom of the disease for the forthcoming patient (Patient 39). Not being able to walk away from the hospital bed, he states that we exist after our death as "a breath". 
"They say something comes out of us. That something has to go somewhere.

-What's that 'something' that goes away? How would you define it?

-A breath ... I suppose." (Patient 39).

Patients seemed to have accepted some of the beliefs about the ancient conception of the afterlife. Based on the mythology he had heard in school and the preaching of the Orthodox religion, the forthcoming patient seemed to be confused:

"I believe in what's being heard or told, that something exists on the other side that makes you ... but I just can't describe it." (Patient 23).

Other patients believed that the souls were not reincarnated into another corporal form but lived on as a spirit. The following three statements come from patients with almost the same characteristics as based on Table 3:

"I believe that the soul is invisible and invulnerable." (Patient 15).

"Some kind of a form, power, or spirit. We must be some kind of these." (Patient 9).

"When we die our soul is dematerialized." (Patient 21).

Many fears are often connected to the unknown and the unexpected. This was an unexpected question for both of the following patients and probably that is why they expressed their fears.

“There come many times that I think I will go see my parents." (Patient 4).

“I am going to find my parents very soon." (Patient 10).

\subsection{Expressions and Definitions of Spirituality}

We further asked the participants to define spirituality or try to describe it in case they do not fully comprehend it. The majority of our participants defined spirituality as a Christian's relationship to God. The Orthodox Church has maintained the Apostolic Faith and tries to hold on to the traditional customs and beliefs of the early church. A lot of patients with religious beliefs answered briefly "Spirituality is our God" (Patients: 7, 41, 46, 54, 69 and 75). Answers like "as a Christian Orthodox I believe that God is our spirituality" (Patients: 29, 44, 50, 64, 70 and 71) were also very frequent.

Christians believe in the healing power of the Mother of God. An elderly participant challenged by a serious disease tends to turn to religious values to help him cope with his illness.

"I can't understand what you mean with the notion spirituality. I have Virgin Mary's protection." (Patient 2).

Nevertheless, the role and purpose of religion is very clear for the Greek society. Older and low educated patients are more likely to be associated with greater God-mediated control beliefs.

"No, there is no spirituality, it's all fairytales, there is only religion." (Patient 47).

Spirituality and religion are not definite for a 71 year old patient with religious beliefs. The notion of "spirituality" is unfamiliar for the participants and that is why religion and spirituality are often mentioned together.

"Spirituality and religiosity are quite similar." (Patient 4).

As the Greek word "pneuma" means spirit, "pneumatikotita" is the Greek word for spirituality. The historical use of the term spirituality has Greek roots. Patients defined spirituality as something quite similar to the spirit. 
"Spirituality is the spirit, what else? If you can't see the spirit, your eyes can't really see." (Patient 11).

"Spirituality is our soul and spirit." (Patient 6).

This study facilitated some detailed and complex descriptions of patients' experiences of spirituality. Spirituality could also be integral to whole patient care. The nature of one's spiritual experience varies and maybe that is the reason why the patients search for wholeness.

"Spirituality is everything ... from what we created to what we lost. I always try to say that I will pull it through today. Well, in here (pointing at the hospital space), only God knows if there is tomorrow." (Patient 49).

Spirituality is an inspiration for something better to come. People try to find acceptance and meaning when facing a chronic illness. One of the challenges of the specific patient (Patient 13) was to keep his spirit alive and for him to try to be optimistic and in a good mood.

"Simple things happen to me every day and I believe that these can't be happening by chance. Spirituality is happiness, love. But, why do you have to hold on to something? You have to move on, to always look on the bright side, not the dark one. If you think bad, only bad things will happen to you." (Patient 13).

Spirituality helps patients keep going on with their lives. The responder did not expect improvements to his health condition because he knew that cure was not possible for many illnesses including COPD.

"Spirituality ? Isn't it great to live and to be well?" (Patient 53).

Patients not only draw strength and comfort from their spiritual beliefs but also use it to fulfill their needs. There seems to be a need to forget and spirituality can provide it. Participant (Patient 8) spoke about forgetting negative life events through spirituality many times during the interview.

"Spirituality makes you forget about your problems." (Patient 8).

Patients' belief was associated with the possibility of an existing "personal God". There was no clear definition of spirituality. The patient formed a concept and an idea of spirituality as the importance of a belief in God.

"I believe that every individual has a 'god' in him/her. There are times that I want to combine wanting with believing, just because I feel so." (Patient 61).

An alternative life philosophy and belief were expressed by the following patient. Having stated that he believes in God and nature, he declines the "existence of spirituality".

"Spirituality? If you don't work on it, who's going to help you? Humans have the power." (Patient 38).

Spirituality is an act of altruism.

"All it takes is to be human and not think of other people's harm." (Patient 27).

While interviewing the following patient in his hospital room and asking him to define spirituality he stated that:

"That is my favorite book. Do you see it on my pillow? (Points to the New Testament)." (Patient 58).

A 69 year old patient with religious and spiritual beliefs also referred to books as an expression of his spirituality.

"I read many books, but due to my health condition, I gave it up. I would particularly read religious and spiritual books a lot. This is the way I express my spirituality." (Patient 9). 


\subsection{Spirituality/Religiosity and Illness Management}

When asked about their health status, a lot of the stories narrated by the patients indicate that they experienced spirituality and religiosity as helpful in dealing with COPD. People with COPD have a well-recognized burden of disabling physical symptoms while breathlessness is one of the most serious. Religious activities seemed to play an important role in everyday life for the next patient.

"I believe in God, I pray day and night and I go to church whenever I can. With the pulmonary disease, when I couldn't breathe, I said: I'm done here ... " (Patient 73).

Patients coped with COPD by comparing it to past experiences. A participant who was hospitalized in the University Public Hospital several times in the past expressed his experience:

"One of the worst things that happened to me in 2011, I now thank God a million times that I am well because I couldn't walk. I would be with a walker, in a catheter, and wearing pampers ... Since I put the oxygen mask on, thank God, things are getting better." (Patient 34).

A patient suffering from severe COPD was referred both to the help provided by God and health care professionals. Coming closer to death, he believed that God kept him alive.

"As for my health status, especially when I refer to the recent incident, I believe that God helped me live. Plus, I thank all the other people, doctors, etc. But I do believe in the power of God. It is what says that our candle is supposed to burn longer to keep me alive." (Patient 23).

A lot of times the specific patient (Patient 65) became tearful during the interview. Although she expressed the need to attend church services more often, two mutually different circumstances kept her away. The first was her husband's cancer problem and the extra time she needed for his care. The other was that she felt discomfort because of the crowded Greek churches.

"My health is not so good. My life is religious but I don't go to church that much because I feel discomfort when attending. Now because of my husband's problem, I don't have the time. Now that my husband is sick, I mean that my life has changed. I cry easily, I get emotional." (Patient 65).

People did not bring up excuses for not going to church. Practical and very serious reasons are holding the next patient back.

"Since I have this problem with COPD, how great can my health be? My life was not happy both at a young age and later when I got married; I didn't lead a good life. Now, I avoid going to church because I can't stand it, I get tired." (Patient 47).

The healing relationship between COPD and spirituality was expressed by several patients. In one woman, her optimism on the progress of her health status was associated with her religious beliefs. She also reported great self-esteem by stating that she "loves herself" and expressing the hope to get better.

"I face other difficulties, but not as great as not being able to breathe ... I am not insecure about my coughing. God forbid, I am not disabled, I hope to get better; people always have hope. I love myself, I believe in Jesus, in religion, in God." (Patient 46).

COPD is linked with heart disease. Although comorbidity affected his daily activities he did not feel disappointed and expressed his trust to God. 
"Life is good, sweet, thank God. Disappointment comes from the people, not from health conditions. As far as my health is concerned, I am not OK because I have COPD, and I have my heart deficiency which makes it hard for me." (Patient 47).

Apart from dealing with the symptoms of COPD, daily survival is a main issue for the following patient. Since the recession, the country has been struggling with high levels of unemployment. Although suffering from a chronic illness, the fact that he is able to work and provide for his family is perceived as an act of God's generosity.

"I am useful because I can still provide for my children ... I say: Thank God. The Almighty keeps me strong." (Patient 68).

There seems to be a variety of influences on people's beliefs about illness, including spirituality and religion. Some patients had a lot of skepticism about the effectiveness of spirituality and religion to medical therapy while some others did not appear to be affected by their religious beliefs at all.

"Health has nothing to do with religion. You can come down with health issues on your own and then "fix" them on your own as well. But, what can you tell me about religion? "Give me a hand and take my kidney out" or "Fix my heart into iron"? That cannot happen." (Patient 49).

The majority of patients did not ask for unrealistic things such as a miracle or a supernatural intervention regarding their health status when dealing with COPD. The patient seemed to be in full knowledge and comprehension of his current situation when he reported a bad health status.

"It's not that miracles will happen overnight, and I will have money, or I will be cured." (Patient 37).

While struggling with the physical aspects of his disease, he seeks no religious support.

"Even though I am sick I do not go to the church as it doesn't suit me anymore." (Patient 11).

\section{Discussion}

Few studies concentrate on the experiences and perceptions of spirituality and religiosity expressed by COPD patients. The findings of this qualitative research cannot be "generalized" but they are an example of the way 75 Greek COPD patients express their spiritual/religious experiences and beliefs in the clinical setting. As noted in the research of Steinhauser et al. (2000), "coming to peace with God and praying" is important to patients [32]. This research tried to be something more than just listen to words. "We believe that we managed to persuade COPD patients to express their sincere feelings about spirituality and religion as the researchers laid trust on the uniqueness of one's experience."

The present study is based on data mainly retrieved from elder patients and members of a single Christian denomination. Our participants were primarily Christian Orthodox, low educated and more than half reported only religious beliefs. Only four patients, suffering from severe $(n=3)$ and very severe COPD $(n=1)$ stated that they had no religious or spiritual understanding of their life. Out of the 75 participants, only one reported that neither spirituality nor religiosity were important factors in his life while the others reported a degree of self-assessed spirituality and religiosity. Non-religious patients seemed to find their meaning through their personal philosophical ideologies, or through their relationships with others or nature [33]. Ehman et al. (1999) queried 177 patients with end stage COPD. They found that $80 \%$ of patients would not mind being asked about religion and $85 \%$ of them noted that their trust in their physician actually increased if that physician addressed their spiritual concerns, $95 \%$ of the patients reported that spirituality was important and wanted their physician to be sensitive 
to their spiritual needs. In the same study, they found that $50 \%$ of the patients, for whom spirituality was not important, felt that physicians should address spiritual issues in the case of serious illness [34].

Religiosity seemed to play a significant role in our participants' everyday life. Belief in the will of God proved to be a strong element for the patients. Our participants seek comfort and guidance from God not only during times of sickness but also in day to day situations. We found that only few of them reported becoming more religious or spiritual after their diagnosis.

The majority of the patients described themselves as Christians and generally seemed to embrace Christian notions of spirituality. Christian spirituality is treated as an extension of Christ's cross: vertically, through the recognition of God's love, justice, mystery and surrender the sovereignty of God, but also horizontally, through an extension of God's kingdom through compassion. The person characterized by this type of spirituality sees him/herself as part of an active and dominant activity of God [35]. Many of our participants stated that they formed the sign of the cross in times of need. They revere the cross very often daily and bless themselves with the sign of the cross as an expression of their relationship with God. Spirituality involves "vertical" and "horizontal" dimensions while covering both supernatural ambitions and conventional social networks [36,37].

The research findings seem to confirm the importance of patients' practicing their beliefs in their daily lives. The majority of patients answered that praying was a request for spiritual/religious intervention and also expressed the need to address God and the Sainthood especially when the individual is in difficulty. A lot of them believed that God and the Saints "co-operate" in order to solve their problems. The biblical reference to healing, when performed by Saints, helped make spiritual healing a commonly accepted practice of early Christianity as referred by Bresler (1979) [38]. Pinches (2007) state that most Christian faiths accept the possibility of this kind of divine action in which God acts in the present time to contravene the natural order [39]. The necessity of patients possessing or referring to icons was an interesting finding in this study. Many seem to seek spiritual support from the healing power of icons. Nes (2004) states that "icons can also open the door to a spirituality that fulfills a deep, religious need" and further adds that "Orthodox iconography has a form which inspires serenity and a content which invites meditation" [40].

We found that religious/spiritual ceremonies may give some of the COPD patients hope and a sense of meaning, which could also help them deal with their illness. Patients who were regular churchgoers seem to attend church to ask for God's help and try to find spiritual support. Church was also believed to be a safe place where one can escape ones problems. Many people find both meaning and hope in their spiritual beliefs and practices. In living with illness and in recovering from it, they search for the meaning of their suffering and look for hope [41]. Krause (2002) states that involvement in religious activity and frequent church attendance may develop closer personal relationship with God. This relationship is leading to better health because being closer to God helps them feel more optimistic and more hopeful [42].

Patients talk about their illness perhaps as an opportunity to see life in a more meaningful way [43]. Apart from the medical help and support, religious/spiritual patients seemed to cope with illness by relying on their beliefs. Main findings of this study between the relationship of religion/spirituality and health outcomes are stated as below:

(1) Having faith on Gods' presence was described as being helpful when dealing with COPD. Patients did not seem to negotiate with God regarding their health status. Krause and Chatters (2005) define God-mediated control as the extent to which people believe it is possible to work together with God to resolve problems [44]. In the research of da Silva et al. (2009), 70 patients suffering from COPD participated. In their study, "spiritual well-being showed to be more related to the feeling of communion with God or a higher power than with existential issues of accomplishment, sense and meaning in life" [45].

(2) However, patients reporting religious and spiritual beliefs did not seem to have unrealistic expectations when dealing with COPD. Hawker (2003) notes that, "we should be careful, however, to avoid misleading spiritual platitudes that bring happiness at the expense of truth." 
It might be upsetting and disappointing leading patients to believe that spirituality brings happiness [46].

Not surprisingly, non-believer patients were the least likely to report a close relationship between religion/spirituality and health outcomes. In the study of Riley et al. (1998), three types of spiritual well-being were identified among a sample of 216 inpatients: (a) religious ( $n=146)$; (b) existential $(n=37)$; and (c). nonspiritual $(n=30)$. Religious people were found to have greater strength and comfort in their faith and believed that they would be fine despite their illness [47].

(3) Church attendance seemed to provide comfort and a "sense" of shelter. However, COPD seemed to prevent patients from regular churchgoing. There was a single report of a patient who was afraid of being "stigmatized" by going to the church due to the effects of his financial hardship.

(4) There were no indications of patients thought of COPD as a punishment from God. On the contrary, there were some participants with great self-esteem who relied on God's help for better days to come. In a comprehensive review of research on spirituality and religion, Koenig (2012) found 69 studies that examined associations with religion/spirituality and self-esteem. Forty-two studies found greater self-esteem among those who were more religious/spiritual while two others reported lower self-esteem [48].

Defining spirituality is certainly not a simple task. This study quotes some simple and some detailed and complex definitions of spirituality. The middle class and low educated Greek patients; mainly men have tried to define the notion of spirituality. Even if the aforementioned socio-demographic characteristics seem to be the limitations of this study, patients managed to enrich it with their own forceful definitions which might actually be the gist of this research. Spirituality is "happiness", "love", "our God", "the spirit", an act of altruism, and our "everything", as stated by the patients. "Spirituality attends to thoughts, attitudes, and dispositions. It invites us to examine and shape our internal world, to take time to reflect upon who we want to be in terms of ideas and values." [27]. According to Sheehan (2005), anyone may have his or her own interpretation of spirituality. The person's age, sex, race, culture, previous personal experiences, and the stage of life the person is experiencing may affect the way his/her spirituality is expressed [49]. But no definition of spirituality " ... can be established independent of the historical use of the term in the English language or the Greek or Latin roots from which the word 'spirituality' is derived," as stated by Reinert and Koenig (2013) [50]. The ancient Greeks believed that the human spirit-psyche-left the body in the form of a breath at the moment of death. "Breath was associated with soul, the source of life, in many ancient cultures, including the Hebrew" [51]. The Greek word for spirituality

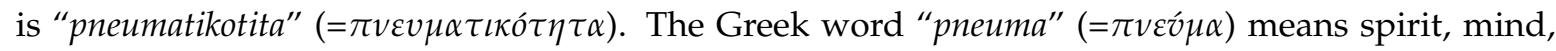
soul and breathing [52]. The term "spirit" derives from the Latin "spiritus" that is breath. The word "Spiro" means spirit, soul, breath and breathing [53]. Thus, both Greek and Latin languages share a common ideology related to the word "spirit".

Results from other qualitative studies seem to support our findings. COPD patients described how their physical limitations forced them to abstain from meaningful activities in everyday life and led them to social isolation [54]. Results of a qualitative study in North Carolina suggest that older patients receiving hospice care may benefit from intervention grounded in issues related to spirituality. Spirituality for these cancer patients had been of lifelong importance and was expressed through active religious involvement [55]. Older African Americans talked about the therapeutic value of specific religious coping methods and also reported that spiritual coping can enhance conventional medical treatments [56]. Cancer patients seem to seek help from spirituality to accept or cope with their disease. They also tend to spend time praying to God alone as they believed that they could obtain peace [57]. African American women with HIV / AIDS defined their spirituality in relation to God, a higher power or a spiritual being [58].

We need to consider some potential limitations, though. As this research is related to spirituality and religion, it has been conducted mainly from a Christian perspective. In this sample of elderly 
Greek COPD patients, they appear to identify themselves primarily as religious and this may reflect the region from which the sample was drawn. Participation in this study was voluntary. Seventy-five patients are only a small percentage related to the thousands of patients suffering from COPD and we do not know if their beliefs and views of spirituality and religiosity are representative. This study included a $92 \%$ of male participants. There is a possible explanation of women's low participation in this study. Fewer women had scheduled their visits to the COPD outpatient clinic of the Pulmonary Department. A large number of COPD patients in Greece remain undiagnosed [59]. Men are more likely to be diagnosed with COPD while prevalence among women is increasing. Two studies in northern Greece showed that COPD prevalence in women aged 21-80 years ranged between $2.5 \%$ and increased with age, [60] reaching $4.8 \%$ in female smokers aged above 35 years old [61]. The lower percentage of women suffering from COPD in Greece is probably related to the low smoking habit of Greek women in rural areas. Researchers reported that women in northern Greece above the age of 60 are nonsmokers [62] and more likely to be never smokers [63].

\section{Conclusions}

Even when being close to religion and spirituality the needs of these COPD patients are typically poorly addressed in the clinical setting. Adopting a more holistic perspective in the clinical setting for COPD patients, spirituality and religiosity can offer suggestions for interventions related to their health issues. Such information may be relevant to understanding the patient's resources for coping with illness and could also be documented in clinical history. Julie Burns Christensen (2001) speaks words of truth: "thousands of spiritual guides have been written. Each religion has its holy books and practices ... Each individual must discern a unique spiritual path, alone or in community. Like a healthy body and mind, a healthy spirit takes nourishment and exercise. When we honor our spiritual natures as we do our corporeal ones, we will find that energy to serve others and to love ourselves" [64]. Spirituality might be the "Breath of God" which helps people answer about the ultimate questions of life, the meaning and relationship of the sacred and the transcendent; especially when living with illness.

Author Contributions: E.T. and K.G. conceived the study; T.K., Z.D., C.H. and, E.K. designed the study; E.T. and T.K. performed the interviews; E.T., T.K. and K.G. analyzed the data; Z.D., C.H. and E.K. contributed analysis tools; E.T. wrote the paper; and K.G. supervised the study.

Conflicts of Interest: The authors declare no conflicts of interest.

\section{Abbreviations}

COPD Chronic Obstructive Pulmonary Disease

\section{Appendix A. The Interview Guide.}

\section{We are now going to ask you some questions about religious and spiritual beliefs. Please try to answer them even if you have little interest in religion.}

In using the word religion, we mean the actual practice of a faith, e.g., going to a temple, mosque, church or synagogue. Some people do not follow a specific religion but do have spiritual beliefs or experiences. For example, they may believe that there is some power or force other than themselves that might influence their life. Some people think of this as God or gods, others do not. Some people make sense of their lives without any religious or spiritual belief.

1. Therefore, would you say that you have a religious or spiritual understanding of your life?

* Religious * Religious and spiritual * Spiritual * Neither religious nor spiritual

2. Can you explain briefly what form your religious/spiritual belief has taken?

3. Does any of the following play a part in your belief? 


a. Prayer
b. Ceremony (e.g., washing before prayer, a religious service, church attendance)
c. Meditation

4. How important to you is the practice of your belief (e.g., prayer, private meditation, religious services) in your day-to-day life? You can explain further if you would like to:

5. Do you communicate in any way with a spiritual power, for example by prayer or contact via a medium? If yes, describe the form of communication.

6. Do you think that we exist in some form after our death? If yes, describe the form.

7. How would you define the term spirituality? If you cannot define it please try to describe it in any way you can.

8. In general, how would you rate your health today?

very good (1), good (2), moderate (3), bad (4) or very bad (5)

9. Do spirituality and religiosity help you cope with your health problems?

Text and Questions from 1-6 are drawn from the "The Royal Free Interview for Religious and Spiritual Beliefs".

Questions 7 and 9 are added by the researchers.

Question 8 is the self-rated health question.

\section{References}

1. Christopher J. Murray, and Alan D. Lopez. "Alternative visions of the future: Projecting mortality and disability, 1990-2020." Lancet 349 (1997): 1498-504. [CrossRef]

2. Jie Hu, and Paula Meek. "Health-related quality of life in individuals with chronic obstructive pulmonary disease." Heart and Lung 34 (2005): 415-22. [CrossRef] [PubMed]

3. Danielle D. Fraser, Carolyn C. Kee, and Ptlene Minick. "Living with chronic obstructive pulmonary disease: Insiders perspective." Journal of Advanced Nursing 55 (2006): 550-58. [CrossRef] [PubMed]

4. Robert M. Shavelle, David R. Paculdo, Scott J. Kush, David M. Mannino, and David J. Strauss. "Life expectancy and years of life lost in chronic obstructive pulmonary disease: Findings from the NHANES III Follow-up Study." International Journal of Chronic Obstructive Pulmonary Disease 4 (2009): 137-48. [CrossRef] [PubMed]

5. Huong Q. Nguyen, and Virginia Carrieri-Kohlman. "Dyspnea self-management in patients with chronic obstructive pulmonary disease: Moderating effects of depressed mood." Psychosomatics 46 (2005): 402-10. [CrossRef] [PubMed]

6. Hedy K. Singer, Robert A. Ruchinskas, Kevin C. Riley, Donna K. Broshek, and Jeffrey T. Barth. "The psychological impact of end-stage lung disease." Chest 120 (2001): 1246-52. [CrossRef] [PubMed]

7. Joel M. Gore, Christopher J. Brophy, and Michael A. Greenstone. "How well do we care for patients end stage chronic obstructive pulmonary disease (COPD)? A comparison of palliative care in COPD and lung cancer." Thorax 55 (2000): 1000-6. [CrossRef] [PubMed]

8. S Robin Cohen, Balfour M. Mount, Michael G. Strobel, and France Bui. “The McGill Quality of Life Questionnaire: A measure of quality of life appropriate for people with advanced disease. A preliminary study of validity and acceptability." Palliative Medicine 9 (1995): 207-19. [CrossRef] [PubMed]

9. Randal R. Cottrell, James T. Girvan, and James F. McKenzie. Principles and Foundations of Health Promotion and Education, 2nd ed. San Francisco: Benjamin Cummings, 2002.

10. Daniel P. Sulmasy. "A Biopsychosocial-Spiritual Model for the Care of Patients at the End of Life." The Gerontologist 42 (2002): 24-33. [CrossRef] [PubMed]

11. Sabine Koch. "Achieving Holistic Health for the Individual through Person-Centered Collaborative Care Supported by Informatics." Healthcare Informatics Research 19 (2013): 3-8. [CrossRef] [PubMed] 
12. Vahid Zamanzadeh, Madineh Jasemi, Leila Valizadeh, Brian Keogh, and Fariba Taleghani. "Effective Factors in Providing Holistic Care: A Qualitative Study." Indian Journal of Palliative Care 21 (2015): 214-24. [PubMed]

13. Nalini Tarakeshwar, Lauren C. Vanderwerker, Elizabeth Paulk, Michelle J. Pearce, Stanislav V. Kasl, and Holly G. Prigerson. "Religious Coping Is Associated with the Quality of Life of Patients with Advanced Cancer." Journal of Palliative Medicine 9 (2006): 646-57. [CrossRef] [PubMed]

14. Tracy A. Balboni, Lauren C. Vanderwerker, Susan D. Block, M. Elizabeth Paulk, Christopher S. Lathan, John R. Peteet, and Holly G. Prigerson. "Religiousness and Spiritual Support Among Advanced Cancer Patients and Associations With End-of-Life Treatment Preferences and Quality of Life." Journal of Clinical Oncology Official Journal of the American Society of Clinical Oncology 25 (2007): 555-60. [CrossRef] [PubMed]

15. Jane Dyson, Mark Cobb, and Dawn Forman. "The meaning of spirituality: A literature review." Journal of Advanced Nursing 26 (1997): 1183-88. [CrossRef] [PubMed]

16. Elizabeth B. MacKinlay. The Spiritual Dimension of Ageing. London: Jessica Kingsley Publishers, 2001.

17. Pamela G. Reed. "An emerging paradigm for the investigation of spirituality in nursing." Research in Nursing $\mathcal{E}$ Health 15 (1992): 349-57. [CrossRef]

18. Debra P. O'Neill, and Elaine K. Kenny. "Spirituality and chronic illness." Image: The Journal of Nursing Scholarship 30 (1998): 275-80. [CrossRef]

19. Peter C. Hill, and Kenneth I. Pargament. "Advances in the conceptualization and measurement of religion and spirituality: Implications for physical and mental health research." American Psychologist 58 (2003): 64-74. [CrossRef] [PubMed]

20. Conrad C. Dal. "Definition of terms: Spirituality versus religiousness." Southern Medical Journal 98 (2005): 1238-39. [CrossRef] [PubMed]

21. Julia D. Emblen. "Religion and spirituality defined according to current use in nursing literature." Journal of Professional Nursing 8 (1992): 41-47. [CrossRef]

22. David N. Elkins, L. James Hedstrom, Lori L. Hughes, J. Andrew Leaf, and Cheryl Saunders. "Toward a Humanistic-Phenomenological Spirituality: Definition, Description, and Measurement." Journal of Humanistic Psychology 28 (1988): 5-18. [CrossRef]

23. Jeffrey S Levin. God, Faith, and Health: Exploring the Spirituality-Health Connection. New York: John Wiley, 2001.

24. Stephanie Ann Farquhar, Edith A. Parker, Amy J. Schulz, and Barbara A. Israel. "Application of qualitative methods in program planning for health promotion interventions." Health Promotion Practice 7 (2006): $234-42$. [CrossRef] [PubMed]

25. Larry D. Culliford. "Spiritual care and psychiatric treatment-An introduction." Advances in Psychiatric Treatment 8 (2002): 249-60. [CrossRef]

26. Janice M. Morse, Ruth R. Wolfe, and Linda Niehaus. "Principles and procedures of maintaining validity for mixed-method design." In Improving Aging and Public Health Research: Qualitative and Mixed Methods. Edited by Leslie A. Curry, Renee R. Shield and Terrie T. Wetle. Washington: American Public Health Association and Gerontological Society of America, 2006.

27. Timothy P. Daaleman, Subashan Perera, and Stephanie A. Studenski. "Religion, Spirituality, and Health status in Geriatric Outpatients." The Annals of Family Medicine 2 (2004): 49-53. [CrossRef] [PubMed]

28. Michael King, Peter Speck, and Angela Thomas. "The Royal Free Interview for religious and spiritual beliefs: Development and standardization." Psychological Medicine 25 (1995): 1125-34. [CrossRef] [PubMed]

29. Michael King, Peter Speck, and Angela Thomas. "The Royal Free Interview for spiritual and religious beliefs: Development and validation of a self report version." Psychological Medicine 31 (2001): 1015-23. [CrossRef] [PubMed]

30. Despoina Sapountzi-Krepia, Marcos N Sgantzos, Alexandra A Dimitriadou, and Ioannis Kalofissudis. "The Greek translation and modification of the Royal Free Interview for Spiritual and Religious Beliefs: The self-report version." ICUS and Nursing Web Journal 14 (2003): 1-13.

31. Despina Sapountzi-Krepia, Vasilios Raftopoulos, Marcos Sgantzos, Evangelia Kotrotsiou, Zoe Roupa-Darivaki, Kalliope Sotiropoulou, Ioanna Ntourou, and Alexandra Dimitriadou. “Validation and test-Retest reliability of the Royal Free Interview for Spiritual and Religious Beliefs when adapted to Greek population." Annals of General Psychiatry 4 (2005): 6. [CrossRef] [PubMed]

32. Karen E. Steinhauser, Nicholas A. Christakis, Elizabeth C. Clipp, Maya McNeilly, Lauren McIntyre, and James A. Tulsky. "Factors considered important at the end of life by patients, family, physicians and other care providers." The Journal of the American Medical Association 284 (2000): 2476-82. [CrossRef] [PubMed] 
33. Betty Ferrel. "Meeting spiritual needs: What is an oncologist to do?" Journal of Clinical Oncology 25 (2007): 467-68. [CrossRef] [PubMed]

34. John W. Ehman, Barbara B. Ott, Thomas H. Short, Ralph C. Ciampa, and John Hansen-Flaschen. "Do patients want physicians to inquire about their spiritual or religious beliefs if they become gravely ill?" Archives of Internal Medicine 159 (1999): 1803-6. [CrossRef] [PubMed]

35. Patricia M. Barnes, Eve Powell-Griner, Kim McFann, and Richard L. Nahin. "Complementary and alternative medicine use among adults: United States, 2002." Seminars in Integrative Medicine 2 (2004): 54-71. [CrossRef]

36. Mary E. McClymont, Silvea E. Thomas, and Michael J. Denham. Health Visiting and the Elderly. Edinburgh: Churchill Livingstone, 1986.

37. Linda A. Ross (nee Waugh). “The spiritual dimension: Its importance to patients' health, well-being and quality of life and its implication for nursing practice." International Journal of Nursing Studies 32 (1995): 457-68. [CrossRef]

38. David E. Bresler. Free Yourself From Pain, 1st ed. New York: Simon \& Schuste, 1979.

39. Charles R. Pinches. "Miracles: A Christian theological overview." Southern Medical Journal 100 (2007): 1236-42. [CrossRef] [PubMed]

40. Solrunn Nes. The Mystical Language of Icons. Norwich: Canterbury Press, 2004.

41. Nancy Kehoe. "Spirituality Groups in Serious Mental Illness." Southern Medical Journal 100 (2007): 647-48. [CrossRef] [PubMed]

42. Neal Krause. "Church-based social support and health in old age: Exploring variations by race." Journal of Gerontology Social Sciences 57 (2007): 332-47. [CrossRef]

43. Christina M. Puchalski, Betty Ferrell, and Edward O’Donnell. "Spiritual Issues in Palliative Care." In Oxford American Handbook of Hospice and Palliative Medicine. Edited by Eduardo Bruera and Sriram Yennurajalingam. New York: Oxford University Press, 2011.

44. Neal Krause, and Linda M. Chatters. "Exploring race differences in a multidimensional batter of prayer measures among older adults." Sociology of Religion 66 (2005): 23-43. [CrossRef]

45. Maíra Shiramizu da Silva, Miako Kimura, Rafael Stelmach, and Vera Lucia Conceição de Gouveia Santos. "Quality of life and spiritual well-being in chronic obstructive pulmonary disease patients." Revista da Escola de Enfermagem da USP 43 (2009): 1187-92. [CrossRef]

46. Matt J Hawker. "Spiritual care based primarily on happiness is dangerous." BMJ 326 (2003): 881. [CrossRef] [PubMed]

47. Barth B. Riley, Robert Perna, Denise G. Tate, Marty Forchheimer, Cheryl Anderson, and Gall Luera. "Types of spiritual well-being among persons with chronic illness: Their relation to various forms of quality of life." Archives of Physical Medicine and Rehabilitation 79 (1998): 258-64. [CrossRef]

48. Harold G. Koenig. "Religion, Spirituality, and Health: The Research and Clinical Implications." ISRN Psychiatry 2012 (2012): 33. [CrossRef] [PubMed]

49. Myles N. Sheehan. "Spirituality and the care of people with life-threatening illness." Techniques in Regional and Pain Management 9 (2005): 109-13. [CrossRef]

50. Katia Garcia Reinert, and Harold G. Koenig. "Re-examining definitions of spirituality in nursing research." Journal of Advanced Nursing 69 (2013): 2622-34. [CrossRef] [PubMed]

51. Victor J. Stenger. "The Breath of God: Identifying Spiritual Energy." In Skeptical Odysseys. Amherst: Prometheus Books, 2001, pp. 363-74.

52. Georgios Giannakopoulos, and Efthymia Siarenou. The Small Greek-English Dictionary. Athens: Koutsoumpos, 1984.

53. Konstantinos Stroumboukis. Italiano-Greco, Greco-Italiano Vocabolario. Athens: Olympia, 1995.

54. E.K. Kristina, and Britt-Marie Ternestedt. "Living with chronic obstructive pulmonary disease at the end of life: a phenomenological study." Journal of Advanced Nursing 62 (2008): 470-78.

55. Kimberly McCord Mackey, and Joyce W. Sparling. "Experiences of Older Women With Cancer Receiving Hospice Care: Significance for Physical Therapy." Physical Therapy 80 (2000): 459-68. [PubMed]

56. Marsha N. Wittink, Jin Hui Joo, Lisa M. Lewis, and Frances K. Barg. "Losing Faith and Using Faith: Older African Americans Discuss Spirituality, Religious Activities, and Depression." Journal of General Internal Medicine 24 (2009): 402-7. [CrossRef] [PubMed] 
57. Khadijeh Hatamipour, Maryam Rassouli, Farideh Yaghmaie, Kazem Zendedel, and Hamid Alavi Majd. "Spiritual needs of cancer patients: A qualitative study." Indian Journal of Palliative Care 21 (2015): 61-67. [PubMed]

58. Safiya George Dalmida, Marcia McDonnell Holstad, Colleen DiIorio, and Gary Laderman. "The Meaning and Use of Spirituality Among African American Women Living With HIV / AIDS." Western Journal of Nursing Research 34 (2012): 736-65. [CrossRef] [PubMed]

59. Markos Minas, Chrissi Hatzoglou, Eleni Karetsi, Andriana I. Papaioannou, Kalliopi Tanoua, Rita Tsaroucha, Eudoxia Gogou, Konstantinos I. Gourgoulianis, and Konstantinos Kostikas. "COPD prevalence and the differences between newly and previously diagnosed COPD patients in a spirometry program." Primary Care Respiratory Journal 19 (2010): 363-70. [CrossRef] [PubMed]

60. Lazaros T. Sichletidis, Ioannis Tsiotsios, Agapios Gavriilidis, Diamantis Chloros, Ioannis Kottakis, Euphemia Daskalopoulou, and Theodoros Konstantinidis. "Prevalence of chronic obstructive pulmonary disease and rhinitis in northern Greece." Respiration 72 (2005): 270-77. [CrossRef] [PubMed]

61. Nikolaos Tzanakis, Urania Anagnostopoulou, Vassiliki Filaditaki, Pandora Christaki, Nikolaos Siafakas, and COPD group of the Hellenic Thoracic. "Prevalence of COPD in Greece." Chest 125 (2004): 892-900. [CrossRef] [PubMed]

62. Lazaros T. Sichletidis, Diamantis Chloros, Ioannis Tsiotsios, Ioannis Kottakis, Ourania Kaiafa, Stella Kaouri, Alexandros Karamanlidis, Dimitrios Kalkanis, and Sotirios Posporelis. "High prevalence of smoking in Northern Greece." Primary Care Respiratory Journal 15 (2006): 92-97. [CrossRef] [PubMed]

63. Andriana I. Papaioannou, Eleni Bania, Evangelos C. Alexopoulos, Eirini Mitsiki, Foteini Malli, and Konstantinos I. Gourgoulianis. "Sex discrepancies in COPD patients and burden of the disease in females: a nationwide study in Greece (Greek Obstructive Lung Disease Epidemiology and health ecoNomics: GOLDEN study)." International Journal of COPD 9 (2014): 203-13. [CrossRef] [PubMed]

64. Julie Burns Christensen. "Spirituality in everyday life." The Western Journal of Medicine 174 (2001): 75-76. [CrossRef] [PubMed]

(C) 2016 by the authors; licensee MDPI, Basel, Switzerland. This article is an open access article distributed under the terms and conditions of the Creative Commons by Attribution (CC-BY) license (http://creativecommons.org/licenses/by/4.0/). 